\title{
THE NEW BORDERS OF SAINT LOUIS
}

\author{
DR. FABRICE DELSAHUT \\ Maître de conférences en Sciences et Techniques des Activités Physiques et Sportives \\ (STAPS) Université Paris 4 Sorbonne (Paris - Paris - France) \\ Membre du CRIS (EA647), Université Claude Bernard Lyon I \\ E-mail: f.delsahut@orange.fr
}

\begin{abstract}
In 1904 the Olympic and Anthropologic Games in Saint Louis, Missouri, were lost in the chaos of the Louisiana Purchase (Universal) Exposition. Although the expected universal spirit, for a long time Saint Louis expressed racial prejudices of its personal. This paper shows up how Sport Sciences and growing up Anthropology acted together in sense of serving questioned causes like racial ranking and colonization right. They were important in improving a feeling of nation in North American that took in grant sport as part of its constitution. The Universal Exposition and Market of Saint Louis offered new possibilities in definition of technological, racial, geographic and corporal borders.
\end{abstract}

KEY-WORDS: Anthropologic conferences, olympic games, race, sport.

A previous article in which we studied the anthropological games in St-Louis first dealt with the conditions of the competitions and the pseudo scientific conclusions which were drawn. That approach did not voluntarily take into account the rising raciological presuppositions that were at the origin of these games and the 
consequences they had on the athletic and colonial future of the so-called primitive populations. So now we intend to analyze those "Tribal Game" from a boarder angle than the only evolutionist paradigm which was a commonly held idea throughout the St-Louis Exhibition. The anthropology days fit into a complex socio-cultural context going beyond the mere expectations of a segregationist America and the Eurocentric racial thinking at the turn of the century.

The varied elements in the International Show celebrating technology as a factor of human progress, the co-organization between the Anthropology and the Physical Training departments, each trying to legitimate their scientific and sports subjects, the international colonialist stakes and the seeking after a unifying nationalism, and finally the North American civic identity question, made these "strange Olympic games" a catalyst of deep society changes. So a more detailed study of that time standards and of rules in debate is now necessary. The Louisiana Purchase Exposition of St-Louis with its impressive structures, its varied exhibitions, its anthropological and Olympic Games enabled the young American Nation - after the end in 1890 of the Frontier dear to J. F. Turner - to precise new technological, racial, geographical and physical frontiers.

\section{RACIAL FRONTIERS AND THE "RACE STUDIES"}

\section{I.।. THE SCIENTIFIC LEGITIMACY OF ANTHROPOLOGY}

Human sciences were becoming more important and anthropology particularly was still a new subject whose references lacked "field work" observations. In the $19^{\text {th }}$ century observation in the field was not essential: ethnologists elaborated theoretical and second-hand work, travelers and missionaries being their only source of information. Carl Lumholtz, then Franz Boas, opened a way which no doubt made the organization of those games easier. Anthropology was essentially based upon anthropometrical measures that known scientists overused all along the Universal Exhibition. From these observations and from biomechanical measures, some very surprising theories were elaborated there and later on.' Dr McGee was bringing

I. Facing the apathy of the Amerindian competitors, a Yale geographer, Ellsworth Huntington, put forward then a curious theory related to the long migratory wave from Siberia. According to him, "The human organism inherits so delicate an adjustment to climate that, in spite of man's boasted ability to live anywhere, the strain of the frozen North eliminates the more nervous and active types of mind. Only those can endure whose nerves lack sensitiveness and who are able to bear long privation and the strain of hunger and cold and darkness. Though the Indian may differ from the white man in many respects, such conditions are probably as bad for him as for any race. For 
his scientific legitimacy and the essential credit to the plan. Besides science played an important part all along those days as if the organizers and also the press were willing to reassure the spectators. For Nancy Parezo "the results of these athletic events were transformed into a so-called 'scientific' conclusion about the superiority or inferiority of different groups of peoples that was transmitted to the press and accepted by countless Americans, reinforcing their preconceptions" (PAREZO, 2005).

So, sciences contributed to justify the aim of the mission - specially "Anthropogeny", a new scientific field proposed by McGee - and to allow the recent ideology called "raciology" to give races a definite position in the human series. This ideology - based upon the differences between skulls, short or long limbs, the color of the skin or of hair - tried to corroborate its daring thesis by using a pseudo-science and its uncertain laws, unverified facts and unjustifiable generalizations. Facing this, the Philippine Natives found difficult to express gratitude towards the New World. The Negritos did not accept any cooperation with those scientists and refused, among others, to take part in an archery competition because they did not know these "tools". For anthropologists all primitive people used bows and arrows. ${ }^{2}$ They also refused that the Institute of Natural History in New York made casts of their heads although they had been promised one dollar each. The St Louis Republican considered this uncompromising attitude as a proof of the Negritos being "the lowest type among the Archipelago inhabitants" unlike their lgorots neighbors. That collection of measures and points of view, accompanied with a display of instruments invented for that purpose, only resulted in the emergence of what S.J. Gould called the "ill-measure of Man" (PICQ, 2007, p. 163). ${ }^{3}$

this reason it is not improbable that long sojourns at way stations on the cold, Alaskan route from central Asia may have weeded out certain types of minds. Perhaps that is why the Indian, though brave, stoical, and hardy, does not possess the alert, nervous temperament which leads to invention and progress." (HUNTINGTON, 1919)

Concerning the Ainu way of moving, scientists strived to prove that their centripetal movements $c$ were essential characteristics of "the lowest types of culture", even the "vestiges of a culture".

2. This idea can be justified first by the fact that the American anthropologist Lewis Henry Morgan (|8|8-|88|) - often considered as the founder of the discipline because he was the first to have observed "in the field" - distinguished in his theory on evolutionism the superior stage of the Savage state, characterized by the invention of the bow and the arrow, the wooden utensils and the use of baskets made of woven bark or rush. Besides, all these savage items were highly represented and used all along the Exhibition. The European travelers who deciphered the New World through heir culture and their references (writings of the Enlightenment among others), contributed to build an allegoric savage picture whose symbols were the bow, the arrow and the feathers, even the pearls.

3. In his book "Nouvelle histoire de l'Homme", Pascal Picq shows that these measures were building "the image of a logical science wich evokes geometry. They refer to the most classical pictures of the measures of Man, such as Leonardo da Vinci's Homunculus. In fact, that famous drawing illustrated the cover page of a very famous professional anthropology magazine: the "Journal of Human Evolution", published recently" (PICQ, 2007, p. I62). 
With Pr McGee's approval, these days allowed the scientists to make psychological researches. With Brunner in the anthropometry department Woodworth explained his work this way: "We have examined about a thousand and one hundred individuals, making the usual physical measures in anthropology and evaluating also the muscular strength, the speed and the accuracy, the sight and the hearing as well as intelligence the best we could, with the help of tables and other simple performance tests we had invented" (WOODWORTH, 1939, p. 17-18).

In a report published in the magazine Science, six years later, he showed that the savages were endowed with sensory capacities far beyond what Europeans could achieved (HOBERMAN, 1999, p. 27). Such results were never linked to possible similar athletic capacities: the mediocre results were convincing enough to the eye of the observers at the time.

The sports program allowed McGee to combine cultural anthropology with physical anthropology (anthropometrics) to present American audiences with examples of what he called "the many long chapters of human evolution". The individuals he gathered for the Universal Exhibition represented the societies and the races of the world and were also living examples of the biological and social evolution of humanity. McGee tried to establish anthropology as a full discipline, with its superior ideas, information and conclusions about the part played by race in the field of man evolution. Everything possible was done to present to the public that supposedly valid experience in the disguise of an athletic competition. He designed the anthropology exhibits as a "Congress of Races and a narrative of human "progress", to summarize and visualize what "the science of man", knew about humanity using an evolutionary model that combined biologically based "race-types" with "culture-grades". The goal of McGee's anthropology was to classify individuals and peoples in terms of progress, and learn as much as possible of the origin and destiny of Man" (PAREZO, 2005).

\subsection{THE MYTH OF BLOOD}

Between 1870 and 1930, the scientific theories which asserted that races were noticeably different in terms of intelligence, athletic capacities and other characteristics remained an acceptable part of the scientific orthodoxy. The racist scientists tried to reach the general public by writing essays. They presented their presuppositions in a way which could touch the great majority, so as to prove that evolution gave special genetic characteristics to some races. Sport provided them with a favorable field of experiment. The hypothesis which prevailed at that time was that Europeans were the dominating race in the world, either on sports grounds or on battle fields, in school debates or in scientific experts 'reports, in the economic competition or in 
political ideas. Contrary to what the press wrote then, those days did not surprise the organizers regarding the natives 'performances. According to McGee, the Savage Days showed "what anthropologists had known for a year, which is the white man was the leader of the races of the world, physically as well as mentally".

It is nevertheless a fact that the main ideas concerning racial science during the first half of the $20^{\text {th }}$ century did not tally with the US being a blend of races: some tried to contradict the idea that racial diversity improved the American athletic results. T Relying on the 1906 scores in the Athens games and in the London ones in 1908, Dr Charles E. Woodruff from the US medical military forces put forward that races offered a crucial clue concerning the mysteries around the Olympic performances. These results, combining scientific racism and Olympic performances, showed an extreme discrepancy with the general belief in the triumphant American melting pot. He refused the sentimental idea of an American race that would be rising from a supposed union of all races. In future, the Olympic facts should be "taken to heart by those who think we are evolving a new type of humanity to be called the 'American' - a type fit to live anywhere from Florida to Alaska [...] Such a type is impossible [...] Nature is merely permitting the types fitted to each locality to survive, and she lets the others die off" (DYRESON, 200 I, p. I 80). The results of the Anthropological games and of the Olympic Games comforted him in the illusion of a knowledge which enabled the construction of a perfect human order on earth. That "gnosis" was materialized by the "Nordic race" ${ }^{4}$ and more generally by the "Nordic idea".

According to Woodruff, the Olympic champions did not belong to the ethnic groups which were part of the "new immigration" at the end of the $19^{\text {th }}$ century and at the beginning of the $20^{\text {th }}$ century, namely people coming from the East and the South of Europe. The majority of the athletic Olympic champions had Nordic looks: clear skin and fair hair. He suggested that the process of natural selection worked particularly well for some racial types under certain climates. He put forward the effect of climate on energy to explain that the best athletes had come from the first and second generations of immigrants. The luminous American skies stimulated the nervous system of the Nordic settlers all along the first influxes of immigrants in the New World. He drew the conclusion that light provided the "basis for a dynamic

4. For Eric Hobsbawm, "the expression "a Nordic race" appears $d$ for the first time in the anthropological classifications of I898. It seems that this expression was "invented" by J. Deniker - in his book Races and peoples of the erath, Paris, 1900 - but it was used again by the racists who considered it convenient to name the "fair dolichocephalic" race which they considered superior above all" (HOBSBAWM, 1992, p. 139). 
life" and explained the passion for sports of the American civilization. His theory was also that too much stimulation from the American light made the number of potential athletes decrease in families who had been living on American soil for a long time. The few athletic champions coming front he south explained why adapting to the environment in warm areas "devitalizes" the Nordic settlers.

The question of the scientific validity of the race theory - either described or explained - was linked to the way it worked in politico-symbolical or "mythical" fields. Confronted to inadequate anti-racist scientific counter-arguments, the political conclusions were that the young Nordic men ruled American society until the New World light made them break down. So Woodruff cared about the fact that the sun reduced the vital forces of the north-European ethnic groups instead of stimulating them: they were now incapable of going on with their natural role of leaders of the American society. According to him, the "real Arya of our philologists" were the masters of the world from time immemorial. He suggested then that "if America is to be at the front of civilization with the other advanced nations, its blood must be constantly recruited from Northern Europe" (DYRESON, 200 |, p. | 80- | 8 |) to replace the American Nordic stock which was continually deteriorated. In Europe, the German eugenicists unreservedly adopted Woodruff's theses.

\section{I.3 THE DIVIDING LINE OF RACES}

Those Anthropological Games were not a mere unhappy manifestation of the Olympic movement. They brought basic answers to the main problem of the $20^{\text {th }}$ century that is as W.E.B. Dubois wrote in 1903: "the problem of the dividing line in colors, of the link between darker races and lighter ones in Asia, Africa, America and on the Oceanic Islands".

Those games had more importance, directly or indirectly, than what has been written. The interpretations of the facts coming from the Days and from the Olympic Games, and the racial myths of the time, make it necessary for a political community not only to form one body but also to visualize this body. This idea of body is important for it presupposes a vision of a global race. "Blood and soul are only different expressions of this unity represented by the Nordic image of man" (VOEGELIN, 2007, p. 17). This double aspect - scientific truth and spiritual type was often at the earth of debates in St Louis and later, as still valid elements of the Valladolid Controversy. The more or less admitted illegitimacy of the athletic results during the Days clashed thoroughly with the arguments linked to the indigenes being intellectually incapables of adapting their motricity, of measuring their efforts or other things. 
These interpretations tell also about the making of the American destiny and throw a light on the origin of the Caucasians-Savages opposition, giving birth later on to the Aryans-Semites opposition. With a background of extreme nationalism, a mixture of social Darwinism, of eugenism (or "racial hygiene"), of race theory and of "Nordic racism" could only provoke the enthusiasm of a great number of biologist, anthropologists and eugenicist doctors. That is why St Louis appears as a sensitive center presenting theses thesis as examples and is also responsible for their interpretation and spreading. The part played by the media is therefore very important.

Confronted to those numerous developments - being either a product of the racialism or of the racism which accompanied St Louis and the following Olympic Games - the mistake was to imagine "the other" from a genetic or a physiological point of view. The problem was first and foremost a question of representation, not of biology, but essentially an idea to stick to. The "Nordic idea" was less a physical type than an ideal to be found and imposed on the American people who had been influenced by history and... climate. The union and the safety of the States depended on that issue.

\section{THE GEOGRAPHIC FRONTIERS AND THE WHITE MAN'S BURDEN}

The vision of a world organized into a hierarchy proposed at Saint-Louis obviously justified the segregationist domestic policy and all colonial aspirations. The Anthropologic Days made American people aware that it was now normal to instill their model all over the world. A paradox was expressed in the heart of the fair: that of an American empire under construction convicted of being, as Herman Melville wrote, "And we Americans are the peculiar, chosen people--the Israel of our time; we bear the ark of the liberties of the world...". We are the pioneers of the world; the advance-guard sent on through the wilderness of untried things, to break a new path in the New World that is ours" (MELVILLE, I850, p. 238-239). As another consequence, the Days fed popular imagination and legitimized the colonialism. This was even a duty, described by Rudyard Kipling as "the White Man's Burden". "The amusing feature" of the "Little Men" involved in a mud fight which was generally

5. «The White Man's Burden » wore in subtitle: The United States and the Philippine Islands and was a support given to the colonization of the Philippines and a reminder of the cost of the imperialist adventures. The expression became an euphemism used as a rallying cry to the western imperialisms which so expressed the terrible weight they had to bear to assume their « noble mission « to bring the civilization to the «barbarians». 
reported by the press (ST. LOUIS REPUBLIC, August 13, 1904, p. 5), constituted an astonishing display which led both American and European spectators to feel morally justified in bringing modern sports (along with the rest of civilization) to the rest of the world" (GUTTMANN, 1984, p. 20). We can wonder if these Days did not come to support or to influence the later stands of Coubertin. "Sport is an eminent factor of colonial enterprises", he wrote ten years later, "so much that colonizing without a strong sportive preparation constitutes a dangerous imprudence" (COUBERTIN, 1914, p. 382). If indigenous peoples could be allowed to practice sports, he first saw those as "a strong instrument of disciplination" (COUBERTIN, 19/2, p. 9) in their long way to civilization. He added that "the theory of right equality for all human races leads to a political line which is against all colonial progress. Without falling, of course, into slavery or even into a softened kind of serfdom, the superior race is perfectly right in denying some privileges of civilized life to the lower race (...). All other races must swear allegiance to the white race, which is superior in essence" (BOULONGNE, 1975). While Jules Ferry declared about the partition of Congo that France was only occupying lands populated of "lower races on which superior races have rights", and Count Arthur de Gobineau declared in his essay "The Inequality of Human Races" ( I 853- | 855) that "the savages of America and Hindus are (physically) by far our inferiors. Niggers have also less muscular vigor", the Baron's comments can sometime appear more moderate, even sweetened.

Whether it was in the grandiose framework of the Exhibition or in that, more intimate, of the Sports Days, the organizers always took care of checking or even justify by all means an American imperialism which was under construction. In 1901, America was a nation confident in her destiny, which thought, as Jules Ferry did, that the greatness of a people was to spread everywhere "her customs, her language, her weapons, her flag, her genius". The Americans, led by President William McKinley, saw a divine intervention in the victorious American-Spanish war. ${ }^{6}$ As for the sociologist Franklin H. Giddins, from the University of Columbia, he declared that the victorious battle of Manilla Bay was the most important historic fact since Charles Martel's victory in $732 \mathrm{AD}$, because "the great question of the twentieth century is whether the Anglo-Saxon or the Slav is to impress his civilization on the world " (CARLSON, 1989, p. 24).

6. On the military plan, the American-Spanish war of 1898 , in spite of its brevity, propelled the United States on the world scene. The prodigious economic growth intervened since the end of the American Civil War having made the United States a world power, number of citizens considered henceforth that their country had to act outside the borders of the country. 


\section{THE PHYSICAL FRONTIERS AND THE GOSPEL OF MUSCLE}

\section{I A NATIONAL SPORTS CONSCIOUSNESS}

The challenge that was put in 1904 regarded the establishment by the young United States of a local relation between the society of the citizens of the forty-five territorial states on one hand, and, on the other hand, the building of a "nation" upon linguistic, racial or other bases which would allow a collective recognition of the membership of a same people. The sport was presented as a possible subject of national federation.

The raise of a national sports consciousness took shape during these Anthropological, then Olympic Days. The first ones strengthened the "white race" in its athletic capacities and the second ones strengthened it in the American omnipotence in sport and, by extrapolation, on the whole world. Lew Carson shows in his article the long "sportification" process of the American society. At the origin of this young turbulent nation, sport was not a divine blessing. The heirs of the Mayflower pilgrims loathed sports activities of any kind and, since the beginning of $17^{\text {th }}$ century; they established a series of more or less crippling ukases. For the theocratic guides of New England, the only way to serve and please God was working and facing the difficulties, thus characterizing an ascetic morality. Choosing the easy way of games meant falling into laziness and idleness, by using diabolic means. The believer, guided by the Holy Spirit, could not rely upon the chance or the prize of the fate, to which was often likened the sports outcome. Consequently, all kinds of games where banished from colonial possessions of Connecticut and Massachusetts.

In the $19^{\text {th }}$ century, the change of the values, the demographic movements and the technological developments affected the lifestyle of the Americans. A softening of the puritanical consciousnesses and a loss of faith in the omnipotence of work resulted, for a rapidly growing urban population, in a new legitimacy of the entertainments. While the physiological benefactions of physical exercises were put forward since Civil War, some began to assign patriotic and democratic values to sport. In 1896, a national leader as Henry Cabot Lodge declared to the students of Harvard: "The time given to athletic contests and the injuries incurred on the playing field are part of the price which the English-speaking race has paid for being world conquerors" (CARLSON, 1989, p. 20). Thirty years later, General Mc Arthur, at the head of the American Olympic delegation, declared: "nothing has been more characteristic of the genius of the American people than their genius for athletics" (CARLSON, 1989, p. 20). In the same way as the thirteen colonies will show themselves as an independent nation on the American flag, the games of the 
colonists will be supplanted by base-ball, a true national pastime able of expressing the fundamental qualities of the emergent Union.

The American sports success at the Olympic Games that followed the Days reinforced the craze for a national practice of sport and for its registration in the national field. 1904 even made it one of its foundations. This also favored the attachment of the public in sports, freshly codified for most of them, which were considered as an integral part of lifestyle and culture.

Sport became "more than any other social activity, the argument which gathers and unifies in the most effective and most long-lasting way" (HEIMERMANN, 2000, p. 42). By extension, this allowed the American International Committee to extend its influence in the decisions to come in the Olympic movement, in particular about the choice of competitions. Sport characterized this spirit of excellence, and training joined among the sciences which were considered capable of resolving all social problems. The present craze of the United States for sport and the faith in the virtues of the physical exercise took root during these Games. The American people found a new pride in the sensational sports success of his athletes, and the cult of the body seized the continent. These Games marked the awareness of the Americans in the superiority of their bodies, of their ways of life and of their culture. Saint Louis registered the sport as an integral part of the American way of life.

\subsection{STRONG BODIES AND HEALTHY MINDS}

The beginning of the American colonialist enterprise, i.e. the movement of expansion towards the outside, also seemed to be made inward individuals. While trying to cross the geographical frontiers, the Americans tried to push away their own physical boundaries via the notion of records.

The Colombian exhibition in 1893 established the triumph of the young conquering nation which realized her "obvious fate", that to bring the Christian civilization to the natives throughout the continent. At this occasion, a young historian named Frederick Jackson Turner defended a personal thesis about the Frontier. According to him, the existence of a zone of virgin lands, its continual reduction and the advance of the American colonization westward explained the American development. In 1904, it was commonly admitted that the Euro-American colonists had tamed the border and that America had lost the big wild spaces which had fed the strong democracy. From now on, the civilization mission implied to 
move the "frontier" beyond the oceans. As they were invited to celebrate the centennial anniversary of the purchase of Louisiana, the Americans faced the issue of finding a new mechanism to strengthen the democratic evolution of American civilization. The sports scientists offered the sporting event as an alternative. The Anthropologic Games and the Olympic Games of 1904 played an essential role in the fact of convincing the American audience that the sport served the interests of progress and national revitalization. What the frontier had made for America in the past, the playgrounds will make for the United States in the 20 $0^{\text {th }}$ century. For Mark Dyreson, " at the Louisiana Purchase Exposition, the expectations placed on the frontier were transferred to the Olympic playing fields. In 1904, as it had in 1803, St. Louis served as a gateway to invigorating the national imagination" (DYRESON, 1993, p. 20). The media reinforced this rising ideology by promoting the Tribal and Olympic Games with an avalanche of records to come, whether they were interracial or Olympic. "On a territory with continental dimension, conquered by pioneers come from different horizons and deprived of marks and references, he (the sport) was the common language, the indispensable link, the priority cement" (HEIMERMANN, 2000, p. 42).

The "Wild West myth" was replaced by sport and physical education, which was nicknamed "the gospel of muscle". St Louis, which was the "gateway to the West", the departure point in the middle of the ideological ground of social dynamism - the American frontier - endeavored to consolidate this new physical frontier. The city underwent then a real civic identity crisis. The industrial boom that followed the Civil War had converted the commercial capital into an industrial city of an uncertain fate. The town, in this early $20^{\text {th }}$ century, suffered chronic urban troubles as overpopulation, ethnic tensions, pollution, and political corruption. The supporters of sport claimed that it could clean all these urban diseases and restore the supposed vitality of the frontier. For the journalist John Brisben Walker, "the difference between the year 1893 at Chicago and 1904 at St. Louis is perhaps more marked in the Department of Physical Culture than anywhere else" (DYRESON, 1993, p. 8). The magnificent sports equipments of the Fair were appointed to produce, as The Cosmopolitan wrote, "strong-bodied, sane-minded citizens". For lack of the records devolved to the sport, the physical education turned out to be the remedy proposed against societal troubles bound to urbanization and industrialization.

From that time, health became the magic word that the Physical Culture Department promoted through numerous conferences. The purpose was to discuss about the ideas of the defenders of an active life dependent on cultural models and on distinctive environmental conditions. For Sullivan, sport and physical training were the determiners of these models. For him, sport built "mind, muscle and morality". 
Mc Gee scheduled a series of public speeches which insisted on the social and political implications of sports. The original inequality of races, dear to Gobineau, found there a new illustration. The white race took place naturally at the top of the evolutionist scale because of its monopoly on three criteria: beauty of the forms, intelligence and above all physical strength. Moreover, this physical strength deserved a particular status since the Department of the same name proposed a number of conferences on the subject with in particular an intervention of McGee entitled: "The Influence of Play in Racial Development, with Special Reference to Muscular Movement". This tragic evolutionist belief which had been set up by Charles Darwin's work "The Descent of Man" took an unprecedented extent with this sports farce since seven gold medals were given to the best contributions within the framework of the "World's Olympic Lecture Course" organized by the distinguished scientist of the sport Luther Halsey Gulick. These various contributions permitted the two protagonists of the Games, Sullivan and Mc Gee, to meet around a strong idea: promote a scientific sports culture. For Sullivan, the study of a "scientific Physical Culture" and the spreading of the sport marked the return in a «wholesome civilization» and the visitors of Saint Louis went to see "the birth of a modern physical education as a science".

\section{CONCLUSION}

The tacit inclusion of the sport in the American constitution took shape during the World Fair and more exactly during the Games, whether they were Anthropological or Olympic.

The Anthropological Games were only a sports version of the human zoos, the mixture of the genres "show-science" which became essential in the last third of the century and the beginning of the 20th century. Millions of Europeans then Americans hurried up to discover these "bands of exotic animals, accompanied by not less singular individuals" (BANCEL; BLANCHARD; LEMAIRE, 2000, p. 16), staged behind railings or fences. This scene made the "savages" more attractive but it was also used to dehumanize the Other One. Built around exoticism, with outfits relating to the stereotypes of that time and of a brutal animalization, these human zoos became places were inequalities exemplified, pointing out colonized and "colonizable" peoples. The Anthropologic Games only brought, for a while, the Other One from out of the enclosure to the Stadium. The sport was then only a means put in the service of a rising "inhuman" anthropology, with its batch of anthropometric and psychometric experiments, in order to justify the racial theories of the moment and to support implicitly the partisans of the colonial conquests. 
This radicalization of the American politics crossed several fields. First of all, it consolidated the belief in a human species divided into "human races" which had to be organized. It also leaned on the omnipotence of the science in particular by founding the "science of the man" as a natural science of the "human races". It consolidated the political ideology according to which it was necessary to order the political action according to a racial ideal, "the Nordic idea" in this particular case, and the spreading of this model outside the borders. The myth of blood was used afterwards as a story of "racial regeneration". Finally, the Fair provided the promise of salvations, at the same time technophile and scientist, of retrospective utopias: nostalgia for the lost "race", or potential utopias: to create the "race" of the future, the "new man", the "American race". In America, this had the effect of arousing the debate between the racist theoreticians and the pioneers of the theoretical "antiracism" as Franz Boas. These last ones tried to disqualify scientifically the essential thesis of the theory of the races which, besides that they conferred an academic respectability to the "instinct of division between the peoples", proved, among others, colonialist policies.

Their purpose was to underestimate the scientific nature of the first doctrines mixing the study of races and eugenics, whether these criticisms concerned, upstream, the modes of categorization and hierarchical organization of the human races, or, downstream, the ideological and political consequences of these racialist constructions, and first of all the functions of legitimization and incitement which they might perform.

\section{As novas fronteiras de Saint Louis}

RESUMO: Em 1904, em Saint Louis, Missouri, os jogos olímpicos e antropológicos perderam-se em meio ao caos de uma exposição universal, a Louisiana Purchase Exposition. Apesar do pretendido espírito universalista, Saint Louis refletiu durante muito tempo os preconceitos raciais de seus organizadores. Considerando este quadro, mostraremos como as ciências do esporte e a nascente antropologia atuaram em conjunto na defesa de causas tão discutíveis quanto a hierarquização racial e o direito de colonização, contribuindo de maneira significativa para o nascimento de uma nação norte-americana que encarou o esporte como parte importante de sua constituição. A Feira Exposição Internacional de Saint Louis ofereceu, assim, uma oportunidade para a definição de novas fronteiras tecnológicas, raciais, geográficas e corporais.

PALAVRAS-CHAVE: Jornadas Antropológicas; Jogos Olímpicos; raça; esporte 


\section{Las nuevas fronteras de Saint Louis}

RESUMEN: En 1904, en Saint Louis, Missouri, los juegos olímpicos y antropológicos fueron perdidos en el caos de una exposición universal, La Louisiana Purchase Exposition. Pese al espíritu universal que se pretendía ver, Saint Louis reflejó durante mucho tiempo los prejuicios raciales de sus organizadores. A partir de estos hechos, trataremos de mostrar cómo las ciencias del deporte y de la antropología naciente se juntaron al servicio de causas tan discutibles como la jerarquización racial y el derecho a la colonización y contribuyeron de manera importante al nacimiento de una nación norte-americana que tomara a pecho el deporte como parte importante en su constitución. La Feria Exposición Universal Internacional de Saint Louis ofreció así una oportunidad para definir nuevas fronteras tecnológicas, raciales, geográficas y corporales.

PALABRAS CLAVE: Jornadas Antropológicas; Juegos Olímpicos; raza; deporte.

\section{BIBLIOGRAPHY}

BANCEL N. ; BLANCHARD P. ; LEMAIRE S. Ces zoos humains de la république coloniale. Le Monde Diplomatique, Paris, p. 16-17, aoüt 2000.

BOULONGNE, Y.-P. La vie et l'œuvre pédagogique de Pierre de Coubertin. Ottawa: Lémeac, 1975.

BROWNELL, S. The 1904 anthropology days and olympic games: sport, race, and american imperialism. Nebraska: University of Nebraska, 2008.

CARLSON, L. Giant patagonians and hairy ainu: anthropology days at the 1904 St. Louis Olympics. Journal of American Culture, Bowling, v. 12, n. 3, p. 19-25, 1989.

COUBERTIN, P. Les sports et la colonisation. Revue Olympique, n. 73, p. 7-10, janv. 1912. Le sport et la société moderne. La Revue Hebdomadaire, n. 25, p. 376-386, 20 juin. 1914.

DAVID, R. F. The universal exposition of 1904. St. Louis: Louisiana Purchase Exposition Company, 1913, p. 524-529.

DYRESON, M. American ideas about race and olympic races from the 1890 s to the 1950s: shattering myths or reinforcing scientific racism?. Journal of Sport History, n. 28, p. 173-2 I5, summer 2001 .

The playing fields of progress: american athletic nationalism and the St. Louis Olympics of 1904. Gateway Heritage, n. 14, p. 4-23, fall 1993. 
GUTTMANN, A. The games must go on: avery brundage and the olympic movement. New York: Columbia University, 1984.

HEIMERMANN, B. "Etats-unis : la patrie du muscle". Outre-Terre, n. 8, p. 4I-46, 2000.

HOBERMAN, J. M. L'universalisme olympique et la question de l'apartheid. X-Alta, n. I . La Tentation du Bonheur Sportif, p. 25-34, janv. 1999.

HOBSBAWM, E. Nations et nationalisme depuis 1780. Paris: Gallimard, 1992.

HUNTINGTON, E. The red man's continent: a chronicle of aboriginal america. New Heaven: Yale University, 1919.

MAGNAGHI, R. M. "America views her indians at the 1904 world fair in St. Louis". Gateway Heritage, v. 4, n. 3, p. 20-29, winter 1983-1984.

MELVILLE, H. White-Jacket. London: Richard Bentley, 1850.

PAREZO, N. Anthropology days, fabricating and testing racial strength and endurance at the 1904 Louisiana purchase exposition. In: ANNUAL MEETING OF THE CULTURAL STUDIES ASSOCIATION, 3. Tucson, 2005. Proceedings... Tucson: University of Arizona, Tucson, apr. 2005.

PICQ, P. Nouvelle histoire de l'homme. Paris: Perrin, 2007.

ST. LOUIS REPUBLIC. Pigmies indulge in mud fight, 13 août [1 904?], p. 5.

TROUTMAN, J. W.; PAREZO, N. J. "The overlord of the savage world": anthropology and the press at the 1904 Louisiana purchase exposition". Museum Anthropology, v. 22, n. 2, p. 17-34, 1998.

VOEGELIN, E. Race et etat. Paris: Vrin, 2007.

WOODWORTH, R. W. Autobiography. In: Psychological issues: selected papers of Robert S. Woodworth. New York, Columbia University, 1939.

Recebido: 31 ago. 2010

Aprovado: I fev. 201 I

Endereço para correspondência Fabrice Delsahut Université Paris IV Sorbonne - IUFM 10 rue Molitor 75016 Paris France 